\title{
CONTRIBUTIONS TO THE CHEMISTRY OF TAPIOLITE - MANGANOTAPIOLITE, A NEW MINERAL
}

\author{
SEPPO I. LAHTI, BO JOHANSON and MARJATTA VIRKKUNEN
}

LAHTI, SEPPO I.; JOHANSON, BO and VIRKKUNEN, MARJATTA 1983: Contributions to the chemistry of tapiolite - manganotapiolite, a new mineral. Bull. Geol. Soc. Finland 55, 2, 101-109.

Microprobe determinations and X-ray diffraction studies of tapiolite specimens from the granitic pegmatites of the Eräjärvi area, in Orivesi, southern Finland, revealed a new manganesedominant analogue of tapiolite. A small crystal, $1.5 \mathrm{~mm}$ long and $0.5 \mathrm{~mm}$ thick, from a narrow lithium pegmatite dyke shows some parts richer in $\mathrm{Mn}$ than $\mathrm{Fe}$. The name manganotapiolite is used for this $\mathrm{Mn}$-dominant member and ferrotapiolite for the common $\mathrm{Fe}$ dominant member of the tapiolite group.

The tapiolite crystal studied is prismatic, showing poorly developed $\{100\}$ faces. Manganotapiolite is dark brown, strongly pleochroic from yellowish brown to reddish brown, but thicker fragments are opaque. In reflected light the colour is grey with a weak bireflectance changing from light brownish grey to grey. Internal reflections are strong with red brown colour. The reflectance values measured in air are: $16.0-15.7(470 \mathrm{~nm}), 14.7-14.1(546 \mathrm{~nm}), 15.0-14.8(589 \mathrm{~nm})$, 15.1-14.6 $(650 \mathrm{~nm})$, and in oil: $4.5-4.0(470 \mathrm{~nm}), 3.9-3.4(546 \mathrm{~nm})$, $4.3-3.8(589 \mathrm{~nm}), 4.3-3.8(650 \mathrm{~nm})$. Density (calc.) is $7.72 \mathrm{~g} / \mathrm{cm}^{3}$ and VHN (100 g load) 711 .

Microprobe analyses on five points of one manganese-rich part gave: $\mathrm{FeO} 6.4,6.2,3.7,3.9$ and $3.2 ; \mathrm{MnO} 6.7,7.7,8.6,9.7$ and 10.2; $\mathrm{CaO} 0.4,0.2,0.6,0.2$ and $0.4 ; \mathrm{Ta}_{2} \mathrm{O}_{5}^{-} 78.1,77.6,78.6,79.8$ and $76.3 ; \mathrm{Nb}_{2} \mathrm{O}_{5}^{-}$ 7.1, 7.6, 7.2, 6.7 and 8.5; $\mathrm{TiO}_{2}^{-} 0.1,0.1,0.0,0.0$ and $0.0 ; \mathrm{SnO}_{2}^{-} 1.0,1.2$, $1.3,1.0$ and 1.0; $\mathrm{Sb}_{2}^{-} \mathrm{O}_{3}^{-} 0.0,0.0,0.0,0.0$ and 0.1 ; Total 99.8, 100.6, 100.1, 101.4 and 99.7 wt. \%. The empirical formula calculated from the mean values of these results (based on $\mathrm{O}=6$ and $\mathrm{Z}=2$ ) is: $\left(\mathrm{Mn}_{0.59}\right.$ $\left.\mathrm{Fe}_{0.32} \mathrm{Ca}_{0.03}\right)_{\Sigma 0.94}\left(\mathrm{Ta}_{1.72} \mathrm{Nb}_{0.27} \mathrm{Sn}_{0.04}\right)_{\Sigma 2.03} \mathrm{O}_{6}$. The $\mathrm{Fe} / \mathrm{Mn}$ ratio of the crystal, however, varies gradually and irregularly from 66/34 to 24/76. The ideal formula of the manganotapiolite unit cell is: ( $\mathrm{Mn}$, $\mathrm{Fe})_{2}(\mathrm{Ta}, \mathrm{Nb})_{4} \mathrm{O}_{12}$, where $\mathrm{Mn}^{2+}>\mathrm{Fe}^{2+}$ and $\mathrm{Ta}>\mathrm{Nb}$.

The X-ray single crystal and powder diffraction studies of the material including the five points analysed showed tetragonal symmetry with space group $\mathrm{P} 4_{2} / \mathrm{mnm}, \mathrm{a}=4.762 \AA$ and $\mathrm{c}=9.272 \AA$ and $\mathrm{V}=210.26 \AA^{3}$. The strongest lines in the X-ray powder diffraction pattern are: 4.24 (40) (101), 3.367 (100) (110), 2.592 (90) (103), 2.381 (60) (200), 1.754 (90) (213), $1.682(60)(220), 1.504(40)(320,302)$ and 1.411 (40) $(303,116)$. Precession photographs show very strong reflections of a cell of the rutile type and twinning on $\{013\}$. The crystal exhibits small inclusions of native antimony, microlite and cassiterite.

Key words: manganotapiolite, ferrotapiolite, new minerals, pegmatite Eräjärvi, Finland.

Seppo I. Lahti, Bo Johanson and Marjatta Virkkunen: Geological Survey of Finland, Kivimiehentie 1, SF-02150 Espoo 15, Finland. 


\section{Introduction}

In 1863 the well-known explorer and mineralogist A. E. Nordenskiöld described a tetragonal $\mathrm{Fe}-\mathrm{Ta}$ oxide tapiolite as a new mineral from the Skogböle pegmatite, Kemiö, SW Finland. Brögger (1897) confirmed the status of two related species with the same chemical formula $(\mathrm{Fe}, \mathrm{Mn})(\mathrm{Ta}, \mathrm{Nb})_{2} \mathrm{O}_{6}$ : the orthorhombic tantalite-columbite and the tetragonal tapiolite-»mossite». Since then chemical analyses have shown that the $\mathrm{Fe} / \mathrm{Mn}$ and $\mathrm{Nb} / \mathrm{Ta}$ ratios of the orthorhombic series vary within wide limits; the iron and manganese-dominant members of columbite (ferrocolumbite and manganocolumbite) and tantalite (ferrotantalite and manganotantalite) are characteristic accessories, especially in granitic pegmatites. On the other hand, tapiolite analyses given in the literature (see Moreau and Tramasure 1965; Beugnies and Mozafari 1968; Clark and Fejer 1978, and Knorring and Fadipe 1981) show that the substitution of $\mathrm{Fe}$ by $\mathrm{Mn}$ and $\mathrm{Ta}$ by $\mathrm{Nb}$ in the tetragonal series is much more restricted. The $\mathrm{Fe} / \mathrm{Mn}$ and $\mathrm{Ta} / \mathrm{Nb}$ ratios of the mineral never drop below unity. Recent chemical analyses and X-ray diffraction studies have revealed that "mossite» does not exist in nature and the name has been discredited (Dunn et al. 1979). The maximum amount of $\mathrm{Mn}$ in tapiolite has been reported by Cech (1973), who shows that tapiolite from Maršikov, Czechoslovakia, contains $5.96 \% \mathrm{MnO}$ and $9.15 \% \mathrm{FeO}$ (or, according to the re-analysis by Clark and Fejer 1978, $4.17 \% \mathrm{MnO}$ and $9.67 \% \mathrm{FeO}$ ), giving the formula $\left(\mathrm{Fe}_{0.65} \mathrm{Mn}_{0.43}\right)_{1.08}\left(\mathrm{Ta}_{1.90}\right.$ $\left.\mathrm{Nb}_{0.07}\right)_{1.97} \mathrm{O}_{6.00}$.

Tapiolite very similar in composition has been reported by Khvostova and Arkhangelskaya (1970), who found tapiolite with $5.63 \% \mathrm{MnO}, 5.49 \% \mathrm{Fe}_{2}^{-} \mathrm{O}_{3}^{-}$and $4.19 \% \mathrm{FeO}$ $(\mathrm{Fe} / \mathrm{Mn}=0.61 / 0.39)$ from the East Siberian pegmatite deposits. Because both of these specimens contain more $\mathrm{Fe}$ than $\mathrm{Mn}$, the minerals must refer to manganoan tapiolites (Fleischer 1971).

The first of the present authors studied the middle Proterozoic granitic pegmatites of the Eräjärvi area in Orivesi, southern Finland and encountered tapiolite as a rare accessory in some dykes in addition to other $\mathrm{Nb}$-Ta minerals (columbite-tantalite, wodginite and microlite) (Lahti 1981). Later, detailed pegmatite studies (tin prospecting) carried out by the authors (M. V. and S. I. L.) in the same area revealed that tapiolite occurs in at least eight pegmatite deposits, most of them lithium pegmatites. X-ray diffraction and microprobe studies showed that one small zonal crystal from a narrow lithium pegmatite dyke is extremely rich in manganese. Some parts of it contain more Mn than $\mathrm{Fe}$, and the mineral is described in this study as a new variety of tapiolite. The first of the authors (S.I.L.) is responsible for the x-ray diffraction studies and physical determinations and second (B.J.) for microprobe analyses. In the light of the discovery, the authors proposed the name manganotapiolite for this Mn analogue of tapiolite solid solution. The Commission on New Minerals and Mineral Names of I.M.A. confirmed the name by vote on 26th March, 1983. Type material will be deposited at the Mineralogical Museum of the Geological Survey of Finland.

On the basis of the discovery of manganotapiolite and on the evidence of experimental studies that there is a complete isomorphous series (Moreau and Tramasure 1965, Turnock 1966), the authors proposed the species name ferrotapiolite for the common Fe-dominant member; tapiolite is considered as a group name covering both species. The Commission on New Minerals and Mineral Names of I.M.A. confirmed this nomenclature of the tapiolite group by vote on 14th June, 1983. 


\section{Occurrence}

The manganotapiolite-ferrotapiolite crystal studied was encountered in the border zone of a pegmatite dyke one metre wide (called the Tiainen dyke by the present authors) south of the Talas dyke whose mineralogy was reported earlier (Lahti 1981). The two dykes are parallel and separated by a mica schist strip some two metres wide.

The Tiainen dyke is slightly zoned. The border zone is some centimetres wide and consists of fine-grained albite-quartz-muscovite pegmatite. The tapiolite crystal studied occurred as a very small prism in albitic plagioclase associated with schorl and apatite. The X-ray studies performed with Gandolfi and Debye-Scherrer cameras on several parts of the crystal, microprobe determinations and microscope studies on the polished sample showed that the mineral has numerous silicate inclusions, very small inclusions of native antimony and a few cassiterite grains. Microlite occurs throughout the sample as many-branched exolutions (Fig. 1.).
Coarse-grained microcline-bearing pegmatite predominates in the middle of the dyke. The biggest microcline crystals and quartz aggregates may reach $10-20 \mathrm{~cm}$ in diameter. The microcline is grey or white and microperthitic. The intermediate zone contains beryl, tourmaline, lepidolite, apatite, FeMn-phosphates, wodginite, columbite, cassiterite, zircon and montebrasite as accessories concentrated on the cleavelandite and sugar albite replacement bodies and fracture fillings crossing the dyke. The most typical accessories are roundish blue green apatite grains and small prismatic crystals of yellow beryl and tourmaline. Tourmaline usually occurs as black or dark green crystals, 2-10 $\mathrm{mm}$ in diameter, but the colour may also be pink, light green or blue. Associated with lithium minerals, the tourmaline crystals miay be zoned with a green core rimmed in pink; some crystals also show longitudinal zonality. Lepidolite occurs as a pink fine-scaled mass or as larger individual sheets often associated with pink-green tourmaline, and small, white montebrasite and brown sicklerite nodules. The sicklerite

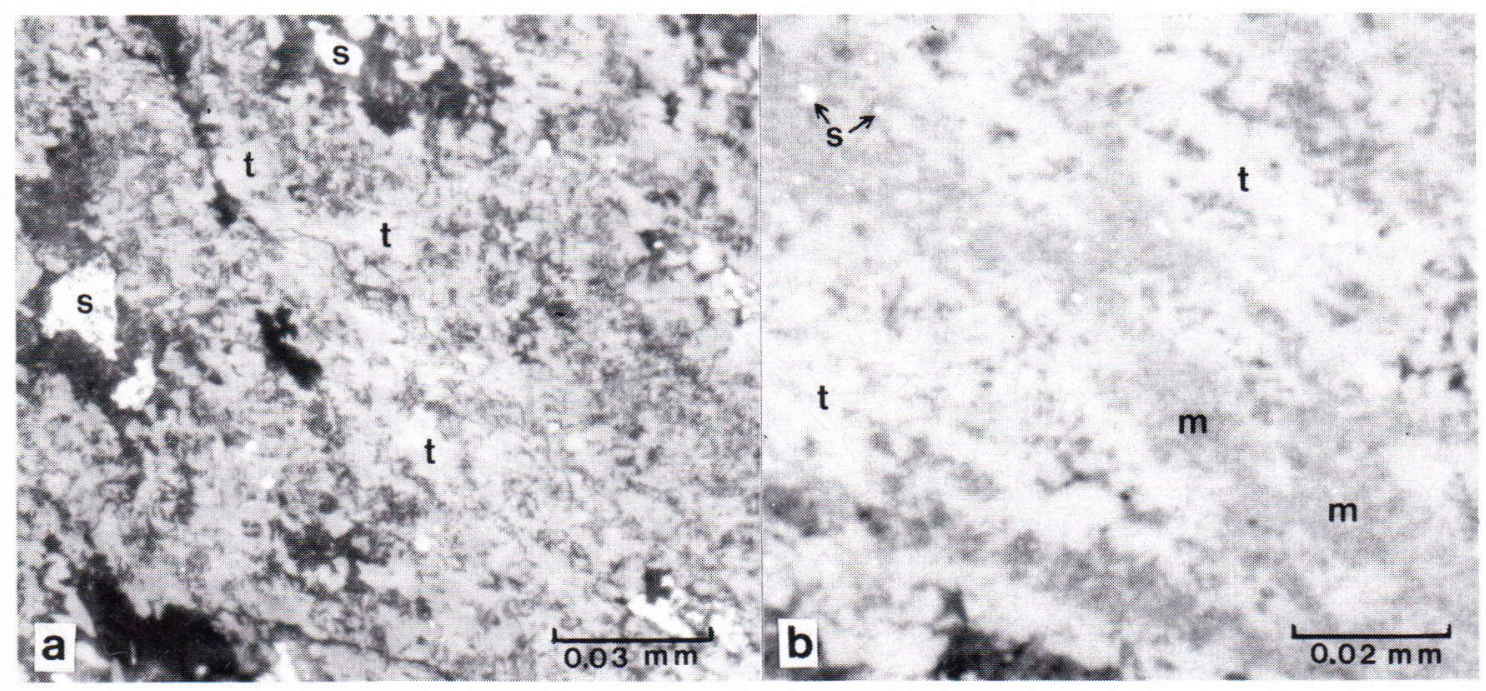

Fig. 1. Photomicrographs of manganotapiolite-ferrotapiolite specimen illustrating a) a normal heterogenous and b) a well-polished »homogeneous» part of a polished section. The irregular black or dark grey parts in tapiolite ( $t$, light grey) consists of small holes and cracks, silicates and microlite (m) exsolu-

tions. Light small grains are native antimony (s). Reflected light, oil immersion, crossed nicols. 
nodules are probably pseudomorphs after lithiophilite as in other pegmatite dykes in the area. According to the microprobe analysis, one sicklerite sample analysed contains 15.4 wt \% FeO (total) and $27.6 \%$ $\mathrm{MnO}$, corresponding to an $\mathrm{Fe} / \mathrm{Mn}$ ratio of $0.35 / 0.65$. The nodule is rimmed by hureaulite, frondelite and vivianite, which also replace the host mineral sicklerite. Wodginite occurs as dark brown anhedral crystals or crystal aggregates, some $\mathrm{mm}$ in diameter, in certain parts of the dyke. Associated minerals may include zircon, cassiterite and black thucholite spherules. Columbite, which is rare in the dyke, was encountered as thin (below $1 \mathrm{~mm}$ thick) black plates with lithium minerals.

\section{Appearance and physical properties}

The crystal studied is prismatic, about $1.5 \mathrm{~mm}$ long and $0.5 \mathrm{~mm}$ thick, but some parts with $\mathrm{Mn}>\mathrm{Fe}$ are no more than $100 \mu \mathrm{m}$ wide. The mineral is opaque with adamantine to submetallic luster. Very thin fragments are translucent. The colour and streak are dark brown. No cleavages were found.

The hardness of the Mn-rich parts measured with a Leitz Durimet device is $711 \mathrm{~kg} /$ $\mathrm{cm}^{2}$ when a $100 \mathrm{p}$ load was used. The result is an arithmetic mean value of seven measurements (limits $665-752 \mathrm{~kg} / \mathrm{cm}^{2}$ ). For lack

Table 1. The reflectance of manganotapiolite measured in air and in oil. SiC standard (National Physical Laboratory no. 87), Shott interference graduated filter, band width $15 \mathrm{~nm}$, objective $45: 1 \mathrm{~A}=0.85$ in air and $60: 1 \mathrm{~A}=0.95$ in oil, immersion oil DIN 58884 .

\begin{tabular}{llr}
\hline $\begin{array}{l}\text { wawelength } \\
\mathrm{nm}\end{array}$ & $\mathrm{R} \%$ in air & $\mathrm{R} \%$ in oil \\
\hline 470 & $16.0-15.7$ & $4.5-4.0$ \\
546 & $14.7-14.1$ & $3.9-3.4$ \\
589 & $15.0-14.8$ & $4.3-3.8$ \\
650 & $15.1-14.6$ & $4.3-3.8$ \\
\hline
\end{tabular}

of material the authors could not measure the specific gravity. The density calculated from the empirical formula is $7.72 \mathrm{~g} / \mathrm{cm}^{3}$.

Small grains of the mineral are pleochroic from yellowish brown to reddish brown, but thicker grains are opaque. In reflected light the colour is grey with a weak bireflectance changing from light brownish grey to grey. Internal reflections are strong with a red-brown colour. The reflectance values measured in air and in oil are given in Table 1. The sample does not polish well and the cracks, holes, inclusions and irregular microlite exsolutions found throughout it must markedly reduce the values.

\section{Chemical data}

Analyses $1-11$ in table 2 show the chemical data of the manganotapiolite-ferrotapiolite crystal examined compared with the chemistry of tapiolite specimens from the other deposits in the area (nos. 13-21). The chemical data on the tapiolite specimens are presented in Figure 2.

The samples were analysed by means of a Jeol Superprobe electron microprobe with accelerating potential $15 \mathrm{kV}$, specimen current $100 \mathrm{nA}$ and beam diameter about $1 \mu \mathrm{m}$. The standards used in the determinations were: manganocolumbite (for $\mathrm{Mn}, \mathrm{Fe}$, $\mathrm{Nb}$, Ta and $\mathrm{W}$ ), ilmenite (for $\mathrm{Ti}$ ), cassiterite (for $\mathrm{Sn}$ ), antimony (for $\mathrm{Sb}$ ) and wollastonite (for $\mathrm{Ca}$ ).

The substitution of the $\mathrm{Mn}(\mathrm{Ta}, \mathrm{Nb})_{2} \mathrm{O}_{6}$ component in tapiolite is limited to $20 \mathrm{~mol}$. $\%$ in most of the specimens studied. Two crystals richer in $\mathrm{Mn}$ were encountered in the same dyke (Tiainen dyke). Analysis 12 (Table 2, Fig. 2) was done on the tapiolite crystal occurring as an inclusion in the wodginite crystal aggregate in the middle of the dyke. Analyses 1-11 were performed on the crystal studied in detail. Most parts of 
Table 2. The chemical composition (as oxides and atoms based on 6 oxygens) of the examined manganotapiolite-ferrotapiolite crystal (no. 1-11) compared with the composition of Mn-rich tapiolite (12) from the same deposit and tapiolite specimens from the other pegmatite deposits of the Eräjärvi area (no. 1321). Microprobe analyses by Bo Johanson and partly by Tuula Hautala.

\begin{tabular}{|c|c|c|c|c|c|c|c|c|c|c|c|}
\hline & $\begin{array}{c}\mathrm{TiO}_{2} \\
\mathrm{Ti}\end{array}$ & $\begin{array}{c}\mathrm{FeO} \\
\mathrm{Fe}\end{array}$ & $\begin{array}{c}\mathrm{MnO} \\
\mathrm{Mn}\end{array}$ & $\begin{array}{c}\mathrm{MgO} \\
\mathrm{Mg}\end{array}$ & $\begin{array}{c}\mathrm{CaO} \\
\mathrm{Ca} \\
\end{array}$ & $\begin{array}{c}\mathrm{Ta}_{2} \mathrm{O}_{5} \\
\mathrm{Ta}\end{array}$ & $\begin{array}{c}\mathrm{Nb}_{2} \mathrm{O}_{5} \\
\mathrm{Nb}\end{array}$ & $\begin{array}{c}\mathrm{WO}_{3} \\
\mathrm{~W}\end{array}$ & $\begin{array}{c}\mathrm{SnO}_{2} \\
\mathrm{Sn}\end{array}$ & $\begin{array}{c}\mathrm{Sb}_{2} \mathrm{O}_{3} \\
\mathrm{Sb}\end{array}$ & $\Sigma O x$ \\
\hline 1 & - & $\begin{array}{l}3.2 \\
0.22\end{array}$ & $\begin{array}{c}10.2 \\
0.70\end{array}$ & $\begin{array}{l}0.0 \\
0.00\end{array}$ & $\begin{array}{l}0.4 \\
0.04\end{array}$ & $\begin{array}{c}76.3 \\
1.68\end{array}$ & $\begin{array}{l}8.5 \\
0.31\end{array}$ & - & $\begin{array}{l}1.0 \\
0.03\end{array}$ & $\begin{array}{l}0.1 \\
0.00\end{array}$ & 99.7 \\
\hline 2 & - & $\begin{array}{l}3.9 \\
0.26\end{array}$ & $\begin{array}{l}9.7 \\
0.66\end{array}$ & $\begin{array}{l}0.0 \\
0.00\end{array}$ & $\begin{array}{l}0.2 \\
0.02\end{array}$ & $\begin{array}{c}79.8 \\
1.75\end{array}$ & $\begin{array}{l}6.7 \\
0.24\end{array}$ & - & $\begin{array}{l}1.0 \\
0.03\end{array}$ & - & 101.3 \\
\hline 3 & - & $\begin{array}{l}3.7 \\
0.25\end{array}$ & $\begin{array}{l}8.6 \\
0.59\end{array}$ & $\begin{array}{l}0.0 \\
0.00\end{array}$ & $\begin{array}{l}0.6 \\
0.05\end{array}$ & $\begin{array}{c}78.6 \\
1.74\end{array}$ & $\begin{array}{l}7.2 \\
0.27\end{array}$ & - & $\begin{array}{l}1.3 \\
0.04\end{array}$ & - & 100.0 \\
\hline 4 & $\begin{array}{l}0.1 \\
0.01\end{array}$ & $\begin{array}{l}6.2 \\
0.42\end{array}$ & $\begin{array}{l}7.7 \\
0.53\end{array}$ & $\begin{array}{l}0.0 \\
0.00\end{array}$ & $\begin{array}{l}0.2 \\
0.02\end{array}$ & $\begin{array}{c}77.6 \\
1.70\end{array}$ & $\begin{array}{l}7.6 \\
0.28\end{array}$ & - & $\begin{array}{l}1.2 \\
0.04\end{array}$ & $\begin{array}{l}- \\
-\end{array}$ & 100.6 \\
\hline 5 & $\begin{array}{l}- \\
-\end{array}$ & $\begin{array}{l}6.9 \\
0.47\end{array}$ & $\begin{array}{l}6.1 \\
0.42\end{array}$ & $\begin{array}{l}0.0 \\
0.00\end{array}$ & $\begin{array}{l}0.8 \\
0.07\end{array}$ & $\begin{array}{c}80.6 \\
1.77\end{array}$ & $\begin{array}{l}6.1 \\
0.22\end{array}$ & - & $\begin{array}{l}1.0 \\
0.03\end{array}$ & $\begin{array}{l}0.1 \\
0.00\end{array}$ & 101.6 \\
\hline 6 & $\begin{array}{l}0.1 \\
0.01\end{array}$ & $\begin{array}{l}6.4 \\
0.43\end{array}$ & $\begin{array}{l}6.7 \\
0.46\end{array}$ & $\begin{array}{l}0.0 \\
0.00\end{array}$ & $\begin{array}{l}0.4 \\
0.03\end{array}$ & $\begin{array}{c}78.1 \\
1.71\end{array}$ & $\begin{array}{l}7.1 \\
0.26\end{array}$ & - & $\begin{array}{l}1.0 \\
0.03\end{array}$ & - & 99.8 \\
\hline 7 & $\begin{array}{l}- \\
-\end{array}$ & $\begin{array}{l}7.7 \\
0.53\end{array}$ & $\begin{array}{l}7.2 \\
0.50\end{array}$ & $\begin{array}{l}0.0 \\
0.00\end{array}$ & $\begin{array}{l}0.1 \\
0.01\end{array}$ & $\begin{array}{c}77.0 \\
1.73\end{array}$ & $\begin{array}{l}6.3 \\
0.24\end{array}$ & - & $\begin{array}{l}0.8 \\
0.03\end{array}$ & - & 99.1 \\
\hline 8 & - & $\begin{array}{l}7.3 \\
0.50\end{array}$ & $\begin{array}{l}6.5 \\
0.45\end{array}$ & $\begin{array}{l}0.0 \\
0.00\end{array}$ & $\begin{array}{l}0.4 \\
0.04\end{array}$ & $\begin{array}{c}75.7 \\
1.68\end{array}$ & $\begin{array}{l}7.2 \\
0.27\end{array}$ & - & $\begin{array}{l}1.1 \\
0.04\end{array}$ & $\begin{array}{l}1.4 \\
0.05\end{array}$ & 99.6 \\
\hline 9 & - & $\begin{array}{l}8.4 \\
0.57\end{array}$ & $\begin{array}{l}6.1 \\
0.42\end{array}$ & $\begin{array}{l}0.0 \\
0.00\end{array}$ & $\begin{array}{l}0.3 \\
0.03\end{array}$ & $\begin{array}{c}77.3 \\
1.70\end{array}$ & $\begin{array}{l}7.7 \\
0.28\end{array}$ & - & $\begin{array}{l}0.8 \\
0.03\end{array}$ & $\begin{array}{l}0.0 \\
0.00\end{array}$ & 100.6 \\
\hline 10 & - & $\begin{array}{l}8.1 \\
0.56\end{array}$ & $\begin{array}{l}5.0 \\
0.35\end{array}$ & $\begin{array}{l}0.0 \\
0.00\end{array}$ & $\begin{array}{l}0.4 \\
0.04\end{array}$ & $\begin{array}{c}78.6 \\
1.77\end{array}$ & $\begin{array}{l}6.2 \\
0.23\end{array}$ & - & $\begin{array}{l}0.9 \\
0.03\end{array}$ & $\begin{array}{l}0.1 \\
0.00\end{array}$ & 99.3 \\
\hline 11 & $\begin{array}{l}- \\
-\end{array}$ & $\begin{array}{l}9.7 \\
0.66\end{array}$ & $\begin{array}{l}4.9 \\
0.34\end{array}$ & $\begin{array}{l}0.0 \\
0.00\end{array}$ & $\begin{array}{l}0.1 \\
0.01\end{array}$ & $\begin{array}{c}78.9 \\
1.73\end{array}$ & $\begin{array}{l}6.7 \\
0.25\end{array}$ & $\begin{array}{l}- \\
-\end{array}$ & $\begin{array}{l}0.8 \\
0.03\end{array}$ & $\begin{array}{l}0.0 \\
0.00\end{array}$ & 101.1 \\
\hline 12 & $\begin{array}{l}0.1 \\
0.01\end{array}$ & $\begin{array}{c}10.2 \\
0.71\end{array}$ & $\begin{array}{l}4.8 \\
0.34\end{array}$ & $\begin{array}{l}0.0 \\
0.00\end{array}$ & $\begin{array}{l}0.1 \\
0.01\end{array}$ & $\begin{array}{c}83.1 \\
1.88\end{array}$ & $\begin{array}{l}2.0 \\
0.08\end{array}$ & $\begin{array}{l}0.3 \\
0.01\end{array}$ & $\begin{array}{l}0.2 \\
0.01\end{array}$ & - & 100.8 \\
\hline 13 & $\begin{array}{l}0.0 \\
0.00\end{array}$ & $\begin{array}{c}12.9 \\
0.91\end{array}$ & $\begin{array}{l}2.9 \\
0.21\end{array}$ & $\begin{array}{l}0.0 \\
0.00\end{array}$ & $\begin{array}{l}0.0 \\
0.00\end{array}$ & $\begin{array}{c}83.6 \\
0.91\end{array}$ & $\begin{array}{l}1.0 \\
0.04\end{array}$ & $\begin{array}{l}0.0 \\
0.00\end{array}$ & $\begin{array}{l}0.4 \\
0.01\end{array}$ & - & 100.8 \\
\hline 14 & $\begin{array}{l}0.0 \\
0.00\end{array}$ & $\begin{array}{c}12.5 \\
0.88\end{array}$ & $\begin{array}{l}2.6 \\
0.19\end{array}$ & $\begin{array}{l}0.0 \\
0.00\end{array}$ & $\begin{array}{l}0.0 \\
0.00\end{array}$ & $\begin{array}{c}84.9 \\
1.94\end{array}$ & $\begin{array}{l}0.6 \\
0.02\end{array}$ & $\begin{array}{l}0.1 \\
0.00\end{array}$ & $\begin{array}{l}0.2 \\
0.01\end{array}$ & - & 100.9 \\
\hline 15 & $\begin{array}{l}0.5 \\
0.03\end{array}$ & $\begin{array}{c}14.6 \\
1.00\end{array}$ & $\begin{array}{c}0.9 \\
0.06\end{array}$ & $\begin{array}{l}0.0 \\
0.00\end{array}$ & - & $\begin{array}{c}75.9 \\
1.69\end{array}$ & $\begin{array}{l}6.1 \\
0.23\end{array}$ & - & $\begin{array}{l}1.3 \\
0.04\end{array}$ & - & 99.3 \\
\hline 16 & $\begin{array}{l}1.9 \\
0.12\end{array}$ & $\begin{array}{c}14.3 \\
0.97\end{array}$ & $\begin{array}{l}1.7 \\
0.12\end{array}$ & $\begin{array}{l}0.0 \\
0.00\end{array}$ & - & $\begin{array}{c}76.1 \\
1.68\end{array}$ & $\begin{array}{c}4.8 \\
0.18\end{array}$ & - & $\begin{array}{l}0.9 \\
0.03\end{array}$ & - & 99.7 \\
\hline 17 & $\begin{array}{l}0.4 \\
0.03\end{array}$ & $\begin{array}{c}14.4 \\
1.01\end{array}$ & $\begin{array}{c}1.3 \\
0.09\end{array}$ & $\begin{array}{l}0.0 \\
0.00\end{array}$ & - & $\begin{array}{c}80.0 \\
1.81\end{array}$ & $\begin{array}{l}2.5 \\
0.10\end{array}$ & - & $\begin{array}{l}1.0 \\
0.03\end{array}$ & - & 99.6 \\
\hline 18 & $\begin{array}{l}0.8 \\
0.05\end{array}$ & $\begin{array}{c}14.6 \\
1.00\end{array}$ & $\begin{array}{c}0.7 \\
0.05\end{array}$ & $\begin{array}{l}0.0 \\
0.00\end{array}$ & $\begin{array}{l}0.0 \\
0.00\end{array}$ & $\begin{array}{c}73.3 \\
1.64\end{array}$ & $\begin{array}{l}5.7 \\
0.21\end{array}$ & $\begin{array}{l}- \\
-\end{array}$ & $\begin{array}{l}3.4 \\
0.11\end{array}$ & - & 98.5 \\
\hline 19 & $\begin{array}{l}0.3 \\
0.02\end{array}$ & $\begin{array}{c}15.9 \\
1.07\end{array}$ & $\begin{array}{l}0.5 \\
0.03\end{array}$ & $\begin{array}{l}0.0 \\
0.00\end{array}$ & $\begin{array}{l}0.0 \\
0.00\end{array}$ & $\begin{array}{c}76.7 \\
1.68\end{array}$ & $\begin{array}{l}6.6 \\
0.24\end{array}$ & $\begin{array}{l}0.0 \\
0.00\end{array}$ & $\begin{array}{l}0.8 \\
0.03\end{array}$ & - & 100.8 \\
\hline 20 & $\begin{array}{l}2.3 \\
0.14\end{array}$ & $\begin{array}{c}16.2 \\
1.06\end{array}$ & $\begin{array}{c}0.4 \\
0.03\end{array}$ & $\begin{array}{l}0.0 \\
0.00\end{array}$ & - & $\begin{array}{c}72.3 \\
1.54\end{array}$ & $\begin{array}{l}8.6 \\
0.31\end{array}$ & $\begin{array}{l}0.0 \\
0.0\end{array}$ & $\begin{array}{l}0.3 \\
0.01\end{array}$ & - & 100.1 \\
\hline 21 & $\begin{array}{l}1.7 \\
0.10\end{array}$ & $\begin{array}{c}14.9 \\
1.01\end{array}$ & $\begin{array}{l}0.3 \\
0.02 \\
\end{array}$ & $\begin{array}{l}0.0 \\
0.00 \\
\end{array}$ & - & $\begin{array}{c}79.2 \\
1.75 \\
\end{array}$ & $\begin{array}{l}3.8 \\
0.14 \\
\end{array}$ & $\begin{array}{l}0.1 \\
0.00 \\
\end{array}$ & $\begin{array}{l}0.2 \\
0.01 \\
\end{array}$ & - & 100.2 \\
\hline
\end{tabular}

- not determined

Sampling localities (see Lahti 1981):

\begin{tabular}{|c|c|c|}
\hline -12. Tiainen & 16. & Seppälänniem \\
\hline 13.-14. Katila & 17. & Keskimetsä \\
\hline Seppälänranta & 18. & Seppälänranta \\
\hline
\end{tabular}

19. Pellonreuna

20. \& 21. Mäenlaki (about $200 \mathrm{~m}$ NEE from the Keskimetsä dyke) 


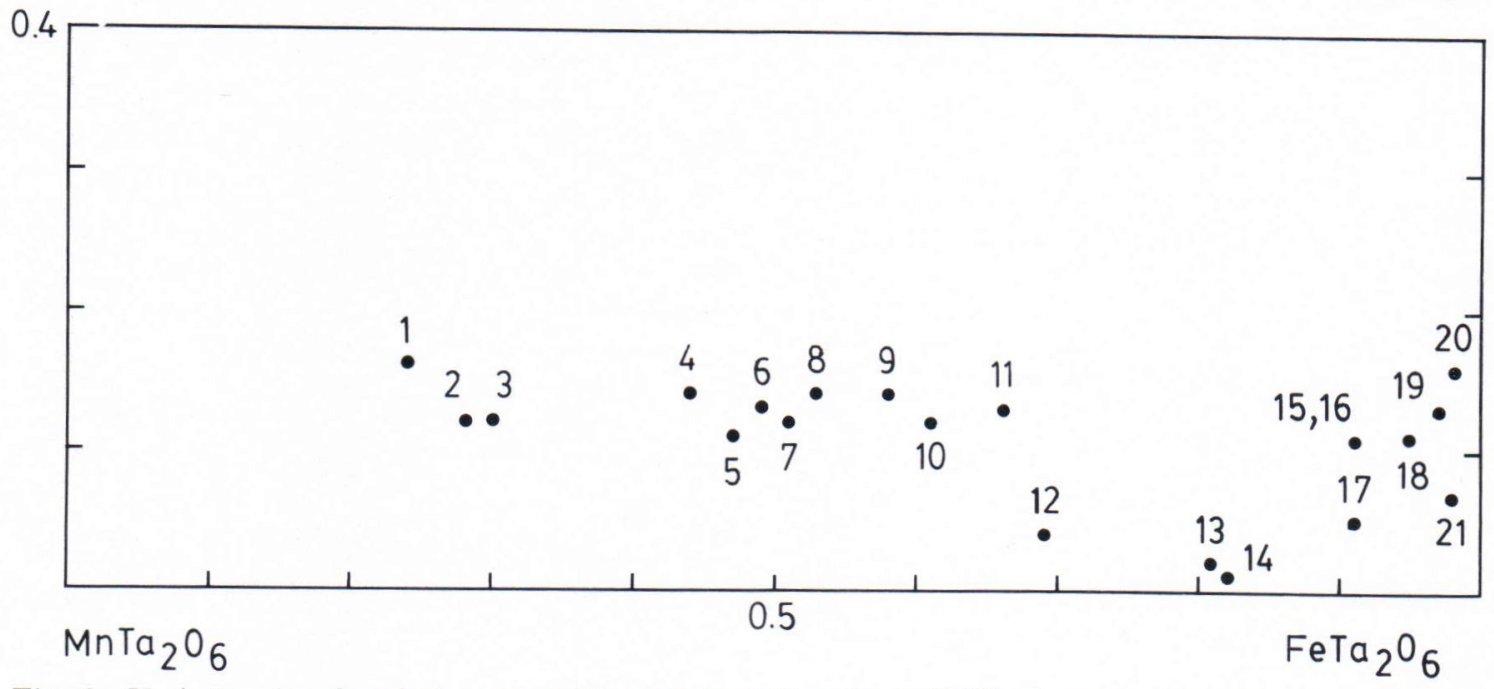

Fig. 2. Variation in chemical composition of tapiolites from Eräjärvi pegmatite area. Numbers of analyses refer to Table 2 .

it contain nearly equal amounts of $\mathrm{Mn}$ and $\mathrm{Fe}$, although some small parts richer or poorer in Mn were also detected. The parts with $\mathrm{Mn}>\mathrm{Fe}$ are no more than $100 \mu \mathrm{m}$ in diameter. They do not represent separate inclusions according to microprobe images, line profiles and quantitative analyses, but the variation of the $\mathrm{Mn}$ and $\mathrm{Fe}$ content is irregular and gradual within the crystal.

Analyses $7-11$ in Table 2 represent the chemical compositions of iron-rich parts of the crystal whereas nos. 1-6 are from a certain Mn-rich part that was later separated for X-ray crystallographical measurement. As Figure 2 shows, the $\mathrm{Fe} / \mathrm{Mn}$ ratio of the crystal varies within extremely wide limits, from $66 / 34$ to $24 / 76$. The empirical formula of the Mn-rich part studied, calculated from the mean values of the results and based on six oxygens, is: $\left(\mathrm{Mn}_{0.59} \mathrm{Fe}_{0.32} \mathrm{Ca}_{0.03}\right)_{\Sigma 0.94}$ $\left(\mathrm{Ta}_{1.72} \mathrm{Nb}_{0.27} \mathrm{Sn}_{0.04}\right)_{\Sigma 2.03} \mathrm{O}_{6}$ when $\mathrm{Z}=2$. This is consistent with the ideal formula of the manganotapiolite unit cell: $(\mathrm{Mn}, \mathrm{Fe})_{2}(\mathrm{Ta}, \mathrm{Nb})_{4} \mathrm{O}_{12}$, where $\mathrm{Mn}^{2+}>\mathrm{Fe}^{2+}$ and $\mathrm{Ta}>\mathrm{Nb}$.
The niobium content does not vary largely in the manganotapiolite-bearing specimen studied, but the range of the substitution of $\mathrm{Ta}$ by $\mathrm{Nb}$ is larger in ferrotapiolite specimens. The amount of "mossite" component $(\mathrm{Mn}, \mathrm{Fe}) \mathrm{Nb}_{2} \mathrm{O}_{6}$ in manganotapiolite varies between 11 and $16 \mathrm{~mol} . \%$ and in the analysed ferrotapiolite specimens between 2 and $16 \mathrm{~mol}$. \%. The analytical results indicate higher contents of calcium in manganotapiolite but much higher titanium in the ferrotapiolite samples. The variation of these elements is moderate in the manganotapiolite-ferrotapiolite crystal.

\section{X-ray studies}

A Mn-rich part (Table 2, anal. 1-6) of the polished tapiolite specimen was separated for X-ray studies. The b-axis and c-axis 0 , 1, 2 and 3-level precession photographs showed tetragonal symmetry for the mineral with space group $\mathrm{P}_{2} / \mathrm{mnm}(\mathrm{k}+1=2 \mathrm{n}$ in 
Table 3. X-ray powder data for manganotapiolite. Debye-Scherrer camera diam. $114.6 \mathrm{~mm}$, Ni-filtered $\mathrm{Cu}$ radiation $\lambda \mathrm{CuK} \alpha 1.54178 \AA$.

\begin{tabular}{|c|c|c|c|}
\hline hkl & d meas. & d calc. & $\mathrm{I} / \mathrm{I}_{\mathrm{o}}$ \\
\hline $002 *$ & 4.64 & 4.64 & 20 \\
\hline $101 *$ & 4.24 & 4.24 & 40 \\
\hline $110^{*}$ & 3.367 & 3.367 & 100 \\
\hline $112 *$ & 2.724 & 2.724 & 20 \\
\hline $103^{*}$ & 2.592 & 2.593 & 90 \\
\hline $200 *$ & 2.381 & 2.381 & 60 \\
\hline 210 & \} 2.122 & 2.130 & \} 10 \\
\hline 202 & & 2.118 & \\
\hline $211^{*}$ & 2.075 & 2.076 & 10 \\
\hline $114^{*}$ & 1.910 & 1.909 & $<10$ \\
\hline $213^{*}$ & 1.754 & 1.754 & 90 \\
\hline 105 & 1.727 & 1.728 & $<10$ \\
\hline 220 & 1.682 & 1.684 & 60 \\
\hline 221 & 1.657 & 1.657 & $<10$ \\
\hline 222 & 1.582 & 1.582 & 10 \\
\hline 006 & 1.545 & 1.545 & 20 \\
\hline 310 & \} 1.504 & 1.506 & \} 40 \\
\hline $\begin{array}{l}302 \\
222\end{array}$ & & 1.501 & \\
\hline 223 & 1.476 & 1.478 & $<10$ \\
\hline $\begin{array}{l}312 \\
303\end{array}$ & 1.431 & 1.432 & $<10$ \\
\hline $\begin{array}{l}303 \\
116\end{array}$ & \} 1.411 & 1.412 & \} 40 \\
\hline 116 & & 1.405 & \\
\hline
\end{tabular}

* reflection used in computing unit cell dimensions

$0 \mathrm{kl}$ reflections). The spots in the films are large owing to the compositional variation of the crystal. The X-ray powder diffraction pattern was recorded from the same grain with a Debye-Scherrer camera. The measured and calculated d-values of the mineral are given in Table 3 . The unit cell dimensions computed from the powder data are: $\mathrm{a}=$ 4.762 (5) $\AA, c=9.272$ (5) $\AA, V=210.26 \AA^{3}$.

The Debye-Scherrer photographs show that the manganotapiolite studied has an ordered structure. The 002 (d $4.64 \AA$ ) and 101 (d $4.24 \AA$ ) reflections, which are lacking in the films of disordered tapiolite (cf. Hutton 1958), are distinct in the powder photographs. The single crystal precession photographs indicate, however, an intermediate structure for the mineral. Manganotapiolite has a strong substructure of rutile type and therefore only some weak reflections can be seen in the c-axis 1 and 2-level precession photographs.

\section{Discussion}

Several authors have studied the composition field of natural and synthetic tapiolite. According to the experimental studies of Moreau and Tramasure (1965), and of Turnock (1966), tapiolite has a rather restricted range of bulk composition in the system $\mathrm{FeTa}_{2} \mathrm{O}_{6}-\mathrm{MnTa}_{2} \mathrm{O}_{6}-\mathrm{FeNb}_{2} \mathrm{O}_{6}-\mathrm{MnNb}_{2} \mathrm{O}_{6}$. Of the end members, only $\mathrm{FeTa}_{2} \mathrm{O}_{6}$ has tetragonal tapiolite structure; the others have an orthorhombic structure corresponding to columbite-tantalite. Turnock (1966) studied the binary system $\mathrm{MnTa}_{2} \mathrm{O}_{6}-\mathrm{FeTa}_{2} \mathrm{O}_{6}$ at one atmosphere total pressure and various temperatures. He showed that the maximum amount of $\mathrm{MnTa}_{2} \mathrm{O}_{6}$ solid solution in tapiolite decreases significantly with decreasing temperature so that at $1500^{\circ} \mathrm{C}$ the extent of substitution is $68 \mathrm{~mol}$. \% $\mathrm{MnTa}_{2} \mathrm{O}_{6}$ and at $1000^{\circ} \mathrm{C} 58 \mathrm{~mol}$ \%. Tantalite exsolves at compositions richer in $\mathrm{Mn}$. To keep manganese and iron divalent the experiments were carried out at low oxygen pressures.

The substitution of $\mathrm{MnTa}_{2} \mathrm{O}_{6}$ in natural tapiolites extends to $40 \mathrm{~mol}$. \% (manganoan tapiolite from Maršikov, Czechoslovakia) according to summaries on the composition of tapiolite given in the literature. Most of the tapiolite analyses, however, show relatively low amounts of manganese (below 20 mol. \% $\mathrm{MnTa}_{2} \mathrm{O}_{6}$ ). Because the manganeserich varieties are rare in nature, their physical properties and unit cell data are not sufficiently known. In his synthetic studies, Turnock (1966) produced several intermediate members between tetragonal $\mathrm{FeTa}_{2} \mathrm{O}_{6}^{-}$and $\mathrm{Fe}_{0.4} \mathrm{Mn}_{0.6} \mathrm{Ta}_{2} \mathrm{O}_{6}$ and reported their unit cell dimensions.

The cell data obtained by the present authors for Eräjärvi manganotapiolite agree 
well with those reported by Turnock for synthetic manganotapiolite (e.g. he gives $\mathrm{a}=4.765 \AA$ and $\mathrm{c}=9.276 \AA$ for $\mathrm{Mn}_{0.6} \mathrm{Fe}_{0.4}$ $\mathrm{Ta}_{2} \mathrm{O}_{6}$, and $\mathrm{a}=4.762 \AA$ and $\mathrm{c}=9.264 \AA$ for $\mathrm{Mn}_{0.5} \mathrm{Fe}_{0.5} \mathrm{Ta}_{2} \mathrm{O}_{6}$ ), but both the a and c-axes are longer than those of manganoan tapiolite from Maršikov, Czechoslovakia $(\mathrm{a}=4.758 \AA$ and $\mathrm{c}=9.271 \AA$ ) reported by Cech (1973). This is consistent with the observation by Moreau and Tramasure (1965), and by Beugnies and Mozafari (1968) and verified with synthetic studies by Turnock (1966) that an increase can be expected in the unit cell volume when the amount of $\mathrm{Mn}$ increases.

The microhardness value of the Eräjärvi manganotapiolite is lower (VHN 711) than that given in published data. Čech (1973) gives VHN 945-1037 (30.2 p load) for the Maršikov manganoan tapiolite, and Beugnies and Mozafari (1968) measured VHN 9311072 for the five ferrotapiolite samples. Vlasov (1966), however, gives much lower hardness values, i.e. $796-824 \mathrm{~kg} / \mathrm{mm}^{2}$, for tapiolite from the USSR. The Eräjärvi manganotapiolite is full of cracks and holes, which must considerably reduce the hardness of the mineral. Similarly the reflectance values are slightly lower in the Eräjärvi manganotapiolite than in the Maršikov manganoan tapiolite. This is, however, consistent with the observations that the reflectance is enhanced with increasing $\mathrm{FeO}$ content. There is no doubt, however, that the cracks, inclusions and exsolutions in the sample cause a drop in the values.

The mineral parageneses and internal structures of the pegmatite dykes in the area indicate that the crystallization of the dykes was a complicated event (Lahti 1981, p. $15-22,74-76)$. The crystallization conditions varied largely throughout the area and therefore many minerals, especially those in thinner dykes and near their contacts, are zoned. The manganotapiolite-ferrotapiolite crystal studied and also columbite, wodginite and some silicate crystals (tourmaline and micas) from the same pegmatite dyke vary considerably in chemical composition. One of the columbite crystals analysed has compositions between $\mathrm{TiO}_{2}$ 1.3, FeO 16.9, $\mathrm{MnO}$ 4.7, $\mathrm{Ta}_{2} \mathrm{O}_{5}$ 15.5, $\mathrm{Nb}_{2} \mathrm{O}_{5}$ 59.0, $\mathrm{WO}_{3}$ 0.7, $\mathrm{SnO}_{2} 0.1$ wt $\%$ and $\mathrm{TiO}_{2}$ 0.3, FeO 6.6, $\mathrm{MnO}$ 10.9, $\mathrm{Ta}_{2} \mathrm{O}_{5} 39.5, \mathrm{Nb}_{2} \mathrm{O}_{5} 44.1, \mathrm{WO}_{3} \quad 0.2, \mathrm{SnO}_{2}$ 0.1 wt $\%$. These analyses show $\mathrm{Fe} / \mathrm{Mn}$ ratios between $0.87 / 0.24$ and $0.37 / 0.62$ (calculated on the basis of six oxygens), which are near to the corresponding values of the manganotapiolite-ferrotapiolite crystal. The composition of some of the analysed wodginite crystals from the middle parts of the dyke varies between $\mathrm{TiO}_{2}$ 0.2, FeO 1.7, $\mathrm{MnO} 8.8$, $\mathrm{Ta}_{2} \mathrm{O}_{5} 73.1, \mathrm{Nb}_{2} \mathrm{O}_{5}$ 3.7, $\mathrm{WO}_{3}$ 0.1, $\mathrm{SnO}_{2} 13.5 \mathrm{wt}$ $\%$ and $\mathrm{TiO}_{2}$ 0.1, FeO 0.7, $\mathrm{MnO}$ 9.7, $\mathrm{Ta}_{2} \mathrm{O}_{5}$ 65.5, $\mathrm{Nb}_{2} \mathrm{O}_{5}$ 3.7, $\mathrm{WO}_{3}$ 0.0, $\mathrm{SnO}_{2} 20.8$ wt $\%$. The $\mathrm{Fe} / \mathrm{Mn}$ ratio of the mineral does not vary much, but the variation in the $\mathrm{SnO}_{2}$ content is marked. The authors have not found reports of wodginite with such a high content of $\mathrm{SnO}_{2}$ in the literature.

Tapiolite is not a stable mineral with columbite-tantalite in the Tiainen dyke or any other dykes of the area, but in some pegmatites wodginite and tapiolite are in close association. Manganoan tapiolite (Table 2, anal. 12) occurs as inclusions in wodginite in the Tiainen dyke and ferrotapiolite crystals were observed in wodginite samples from the Pellonreuna and Keskimetsä dykes (Lahti 1982). The observations are consistent with the experimental studies. With reference to the studies by Turnock (1966), the presence of tapiolite indicates low oxygen pressure and that of columbitetantalite much higher oxygen pressure. The oxygen fugacity in the melt was probably one of the most important factors controlling the crystallization of Nb-Ta minerals in different parts of the pegmatite dykes. 
Acknowledgements. The authors are indebted to Dr. Kari Kojonen (the University of Helsinki) for the reflectance and hardness measurements. Mrs. Tuula Hautala carried out some of the microprobe determinations. Mrs. Mirja Saarinen helped in the X-ray diffraction studies, Mr. Markku Tiainen and Mr. Kari Hautala in the field studies. Miss Lea Aho kindly took the photographs.

\section{References}

Beugnies, A. and Mozafari, Ch., 1968. Contribution à l'étude des propriétés des columbotantalites et des tapiolites. Ann. Soc. Géol. Belg. 91, $35-91$.

Brögger, W. C., 1897. Uber den Mossit und über das Krystallsystem des Tantalit (Skogbölit) aus Finnland. Videnskabsselsk. Christiania (Oslo) srk., 1 Math-Nat. Kl. 7, 1-19.

Čech, František, 1973. Manganoan tapiolite from northern Moravia, Chechoslovakia. Acta Univ. Carolinae - Geol. Rost vol., No. 1-2, $37-45$.

Clark, A. M. and Fejer, E. E., 1978. Tapiolite, its chemistry and cell dimensions. Min. Mag. 42, 477-480.

Dunn, P. J.; Gaines, R. V. and Kristiansen, R., 1979. Mossite discredited. Min. Mag. 43, 553554.

Fleischer, M., 1971. New mineral names (Manganotapiolite $=$ manganoan tapiolite). Am. Mineral. 56,1122 .

Hutton, C. Osborne, 1958. Notes on tapiolite, with special reference to tapiolite from southern Westland, New Zealand. Am. Mineral. 43, $112-119$.

Khvostova, V. A. and Arkhangelskaya, V. N., 1971. A find of a manganese species of tapiolite. Dokl. Akad. Nauk. SSSR 194, 128-129.
The diagram was drawn by Miss Liisa Siren and the manuscript was typed by Mrs. Helga Leppänen.

Professor Atso Vorma and Dr. Kai Hytönen read the manuscrip critically and gave valuable suggestions.

We express our cordial thanks to all the above persons for their help.

von Knorring, Oleg and Fadipe, Akinola, 1981. On the mineralogy and geochemistry of niobium and tantalum in some granite pegmatites and alkali granites of Africa. Bull. Minéral. 104, 496-507.

Lahti, Seppo I., 1981. On the granitic pegmatites of the Eräjärvi area in Orivesi, southern Finland. Geol. Surv. Finland Bull. 314, 82.

Lahti, Seppo I., 1982. Uusi pseudorombinen wodginiittimuunnos Eräjärven pegmatiiteista. Summary: A new pseudo-orthorhombic wodginite variety from the Eräjärvi pegmatite area. Geologi 34, 6-7.

Moreau, J. and Tramasure, G., 1965. Contribution à l'étude des séries columbite-tantalite et tapiolite-mossite. Ann. Soc. Géol. Belg. 88, 301-390.

Nordenskiöld, A. E., 1863. Beskrifning öfver de i Finland funna mineralier. Helsingfors (Helsinki). $177 \mathrm{p}$.

Turnock, A.C., 1966. Synthetic wodginite, tapiolite and tantalite. Can. Mineral. 8, 461-470.

Vlasov, K. A. (editor), 1966. Geochemistry and mineralogy of rare elements and genetic types of their deposits. Vol. 2, Mineralogy of rare elements. S. Monson Wiener Bindery Ltd., Jerusalem. 945 p.

Manuscript received, April 8, 1983 